Discussion Paper No. 10-022

\title{
99 Cent:
}

\section{Price Points in E-Commerce}

Franz Hackl, Michael E. Kummer, and Rudolf Winter-Ebmer

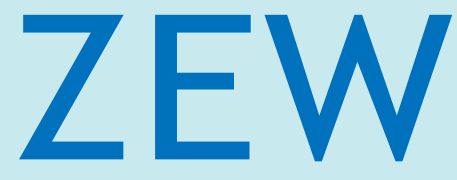

Zentrum für Europäische Wirtschaftsforschung $\mathrm{GmbH}$

Centre for European

Economic Research 
Discussion Paper No. 10-022

\title{
99 Cent: \\ Price Points in E-Commerce
}

\author{
Franz Hackl, Michael E. Kummer, \\ and Rudolf Winter-Ebmer
}

Download this ZEW Discussion Paper from our ftp server:

ftp://ftp.zew.de/pub/zew-docs/dp/dp10022.pdf

Die Discussion Papers dienen einer möglichst schnellen Verbreitung von neueren Forschungsarbeiten des ZEW. Die Beiträge liegen in alleiniger Verantwortung der Autoren und stellen nicht notwendigerweise die Meinung des ZEW dar.

Discussion Papers are intended to make results of ZEW research promptly available to other economists in order to encourage discussion and suggestions for revisions. The authors are solely responsible for the contents which do not necessarily represent the opinion of the ZEW. 


\section{9c: Price-Points in E-Commerce: Non - Technical Summary}

This paper attempts to shed light on the pricing behaviour of firms or sellers in market places with price competition. In particular, it aims at testing the mechanism that lies at the heart of one of the most famous models in economics, namely the Bertrand model of competition. This model suggests that firms' profits will be zero as soon as there are at least two sellers in the market. The model is built on the idea that consumers will go to the cheapest shop, even if the differences in prices are "infinitesimal”. As a result, firms are tempted to undercut their opponents' price by a small amount and they do so over and over until they end up charging the cost at which they produce their products.

However, the underlying assumption is at odds with the observation that consumers typically do not care very much about a single cent and the predicted outcome clearly goes against the fact that many prices end in 99c. If sellers really charged the price at which they buy or produce a good or a service, we should observe all possible price endings. Basu (2006) argues that the prevalence of 99 cent prices in shops can be explained by rational consumers who disregard the rightmost digits of the price. This "bounded rational" behaviour leads to an Bertrand equilibrium with positive mark-ups allowing firms to make at least small profits.

We use data from an Austrian price comparison site, which bears the advantage that in such an environment other factors than price both can be observed online and play a minor role. Price comparison sites are therefore highly suited for our test.

We find results highly compatible with Basu's theory. We can show that price points - in particular prices ending in 9 - are more frequent than other endings and have significant impact on consumer demand. This shows that the mechanism that was postulated by Bertrand is not in place. Consumers do not necessarily choose the cheapest price and they even less do so when the Euro digits of the price are the same (i.e. when the difference is small). Moreover, the nine-ending prices are sticky: neither the price-setter itself wants to change them nor the rivals do underbid these prices, if they represent the cheapest price on the market. This might either show that shops seem to believe that it is no use to only slightly undercut a rival's price if this doesn't trigger a change in the Euro, or it is an indication that there might be some sort of silent agreement to not undercut a price ending in 9 .

Our findings shed new light on the behaviour of consumers and firms, and propose that theoretical investigations on competitive behaviour should consider "discrete state spaces", i.e. markets where the smallest plausible price change is by a Euro or at least by a full Cent. 


\section{9c: Price-Points in E-Commerce. Das Wichtigste in Kürze}

Häufig enden Preise auf 99 Cent oder werden langlebige Konsumgüter wie PCs oder Autos mit Preisen ausgezeichnet, die mit 99 oder 999 Euro enden. Das Ziel dieser Arbeit besteht darin, diese Beobachtung empirisch zu untersuchen und zu testen, ob sie auch auf Onlinemärkten zu finden ist. Dabei sollen jene theoretischen Modelle getestet werden, die versuchen eine ökonomische Erklärung für dieses Verhalten zu finden, ohne die Annahmen anderer zentraler Modelle der Ökonomie zu verletzen.

Eines der wichtigsten Modelle zur Erklärung des Wettbewerbsverhaltens von Firmen ist das Bertrand-Modell. In diesem Modell reagieren Kunden auf minimale Preisänderungen und Firmen unterbieten sich gegenseitig, da sie so ihren Marktanteil schlagartig erhöhen können. Im Gleichgewicht genügen schon zwei Firmen, damit die Produkte ohne Gewinn verkauft werden und es bleiben nur jene Firmen im Markt, die zu diesem Preis liefern können.

Die Annahmen und Vorhersagen dieses Modells würden implizieren, dass Produkte ohne Gewinn direkt weiterverkauft werden und dass alle Endungen gleich häufig vorkommen. Vor allem wenn die Kund/innen auf jede noch so kleine Preisänderung reagierten, sollte man nicht erwarten, dass Preise mit größerer Häufung an der Schwelle von einem Preis mit 9 Euro und der nächsten vollen Zehnerstelle auftreten.

Dennoch kann dieses Verhalten beobachtet werden und die Frage stellt sich, worin die Erklärung für dieses Phänomen liegt. Solch einen Erklärungsversuch leistet das Modell von Basu. In diesem Modell reagieren die Kund/innen nicht mehr auf jeden noch so kleinen Preissprung. Stattdessen beachten sie, um beim Vergleichen der Preise Aufwand zu sparen, nur die vorderen Stellen eines Preises und nehmen für die letzten (ignorierten) Stellen einfach an, dass sie auf 9 enden. Das derart modifizierte Modell gelangt zu einem Gleichgewicht, in dem alle Händler einen (oder denselben?) Preis setzen, der tatsächlich auf 9 endet und der die Produktionskosten übersteigt. So können die Anbieter geringe Gewinne erzielen.

Die vorliegende Arbeit verfolgt das Ziel, diese Hypothesen mit Daten der OnlinePreisvergleichsseite www.geizhals.at zu testen. Preisvergleichsseiten im Internet, auf denen die Händler nach ihrem Preis sortiert werden, sind einem Markt wie jenem im Bertrandmodell sehr ähnlich, sodass sie ein gutes Testfeld darstellen. Mit den Daten von über 20.000 Produkten und 820.000 Angebotspreisen wird untersucht, ob Preise häufiger auf 9 enden und ob Angebote mit der Preisendung 9 häufiger nachgefragt werden und als Angebote mit anderen Preisendungen. Außerdem wird analysiert, ob Online-Shops solche Preise länger beibehalten bzw. ob Mitbewerber/innen einen „Neunerpreis“ zögerlicher unterbieten als runde Preise (z.B.: €500) oder andere Preise. Dabei wurde mit der Methode der Instrumentenvariablen und der Ereigniszeitanalyse gearbeitet.

Die Ergebnisse der Studie zeigen deutlich, dass Preise häufiger auf 9 enden und dass OnlineShops solche Preise länger beibehalten als Preise mit anderen Endungen. Darüber hinaus kann erstmals gezeigt werden, dass die Konkurrenz den Preisführer eines Produktes zögerlicher unterbietet, wenn dieser einen „Neunerpreis“ gewählt hat.

Insgesamt sind diese Ergebnisse im Einklang mit dem Modell von Basu. Die Ergebnisse legen nahe, dass gewisse Aspekte der Standardmodelle mit anderen Annahmen modelliert werden sollten. Vor allem sollte dem Umstand Rechnung getragen werden, dass üblicherweise nur diskrete Preisschritte wahrgenommen werden. 


\title{
99 cent: \\ Price Points in E-Commerce*
}

\author{
Franz Hackl Michael E. Kummer Rudolf Winter-Ebmer \\ University of Linz \\ ZEW Mannheim \\ University of Linz \& IHS, Vienna
}

January 20, 2010

\begin{abstract}
Basu (2006) argues that the prevalence of 99 cent prices in shops can be explained with rational consumers who disregard the rightmost digits of the price. This bounded rational behaviour leads to a Bertrand equilibrium with positive markups. We use data from an Austrian price comparison site and find results highly compatible with Basu's theory. We can show that price points - in particular prices ending in 9 - are prevalent and have significant impact on consumer demand. Moreover, these price points are sticky; neither the price-setter itself wants to change them neither the rivals do underbid these prices, if they represent the cheapest price on the market.
\end{abstract}

JEL-Classification: L11, D41, C41

Keywords: Competitive Behaviour, Pricing Behaviour, E-Commerce, Pricing in the Nines, Focal Pricing.

\footnotetext{
${ }^{*}$ Correspondence: Johannes Kepler University of Linz, Department of Economics, Altenbergerstr. 694040 Linz, Ph.: +4370 2468 8333, Email: franz.hackl@jku.at. This research was supported by grant 12444 of the Austrian National Bank's Jubilee Fund. Thanks to Christine Zulehner and seminar participants at Bocconi, Milano, Essen (RWI), Hannover and Linz for helpful comments and to geizhals.at for giving us access to the data and providing useful advice.
} 


\section{Introduction}

This paper analyzes the role of price points in consumers' purchasing decisions and sellers' price setting behavior of e-commerce markets. Price Points are defined as values with special price endings that are frequently used, i.e. the prevalence of 0-ending (also referred to as "even prices") and 9-ending prices ("just-below prices" or "odd prices"). While previous explanations for this phenomenon rely on costumer's perceptions of these price points - i.e. 9-ending prices convey a particular image of a product (image effect) - Basu (2006) explains such price-setting as a rational strategy of oligopolists in a retail market: If - due to information-processing difficulties - consumers disregard the right-most digits of the price; it might be rational for firms to set prices with a 99-ending in equilibrium. By doing so, firms can increase their prices somewhat and escape the zero profit forecast of the Bertrand equilibrium in a retail market (level effect).

Whereas previous research analyzes these price points in offline-markets (scanner data from supermarkets, real estate markets) we focus on online-markets. The lack of studies in emerging e-commerce markets is surprising given that the digital revolution might change our understanding of the firm pricing process. One might argue that the lack of comprehensive studies in online markets can be explained with less pronounced problems of price comparison: less cognitive difficulties to memorize and compare products of different retailers. In particular, at a price comparison site all price offers for a specific product can be seen at one mouse-click. On the other hand, we still observe price obfuscation (Brynjolfsson and Smith, 2000) - e. g. by variation in shipping cost - and service differentiation between e-tailers so that the idea of strictly ascending price listings looses importance. We will show that - although less than in brick-and-mortar stores - we do see a considerable proportion of odd as well as even prices in online shopping.

Most of the studies in offline markets analyze very specific issues of price points either on the demand side in form of field or laboratory experiments or on the supply side in form of price rigidity analysis. The focus and innovation of our paper lies in the consistent and comprehensive analysis of both sides of the online market: on the one hand the analysis of pricing strategies with price points has to consider price-setting decisions of firms; on the other hand, 
demand regularities on the part of the buyers have to be identified within a consistent data set. Only if both sides of the market show consistent reactions correct conclusions on price points can be drawn: If odd (or even) prices turn out as equilibrium outcomes, they should prevail longer as comparable nonfocal prices. Beyond that, price points should behave consistently in market equilibrium situations: as we are the first to observe the whole market, we can look at price stickiness for prices set by random firms, but also at prices for price-leaders. Basu's (2006) model predicts: if a market equilibrium results in focal prices ending in 99 cent, other firms might be less willing to undercut this price point.

We use comprehensive data from Austria's largest price comparison site to test theories on price points. While most previous studies consider only buying intentions, small samples and a limited number of products, our data has the advantage that we can observe the entire market place with all competing shops. We use price information on 24473 products posted by 714 sellers together with information about referral clicks and last-click-throughs which are typically used as demand indicators in e-tailing.

We show that 99-ending prices - in general focal prices - are prevalent in a market environment where they should least be expected to be. Our results are highly supportive of Basu's theory: consumers disregard cent in their shopping behavior, prices are more stable if they end with 9. Moreover, best-prices ending in 9 or 99 are not changed by the price-setting firms and are less likely to be underbid by the rivals of the shop.

\section{Literature}

\subsection{Theories for price points}

Researchers have focused mainly on two consumer-oriented explanations for the phenomenon of focal prices ${ }^{1}$ (Stiving and Winer, 1997):

\footnotetext{
${ }^{1}$ There is a wealth of operational or ad-hoc explanations. The most famous example is the anecdotal account (Stiving and Winer, 1997) of shop-owners, who posted prices which would force the clerks to give back some small change in order to force their staff to register the transactions rather than pocket the money. Among other ad-hoc theories Monroe (1973) mentions (and refutes) views that the number 9 might be considered a magical number with special properties. Clustering has also been considered as a tool to maintain tacit collusion
} 
(i) The first approach has been called level effect, left digit effect or left to right processing (Thomas and Morwitz (2007), Basu (2006) or Thomas and Morwitz (2005)). The basic idea is the assumption that consumers use a heuristic to calculate, compare and memorize prizes, due to their limited brain-capacity to process prices exactly: they read prices from the left and, in particular, they disregard cent prices. As a result of this boundedly rational behavior, the consumers tend to overestimate the gap between prices differing only by a small amount, if the lower price has a smaller left digit (e.g.: €3.00 vs. €2.99).

This theory has only recently been formalized in a Bertrand-Equilibrium model (Basu, 2006). The paper assumes boundedly rational consumers, who do not bother to take into account what's after the comma. Instead, they "guess" that it is the average of all the last digits of products on the market. This setting is used to analyze the market equilibria in a Bertrand-setting where firms can post prices but cannot affect quantities.

The model is relevant for two reasons: Firstly, the mechanism attacks the Bertrand-paradox: Since consumers ignore the cent ending, undercutting a 9ending price by less than a full euro does not generate additional turnover; on the other hand, it reduces the profit margin. As a consequence, firms who want to undercut will undercut by a full euro; undercutting with small amounts does not make sense. Secondly, Basu's model generates an equilibrium in 99-prices, that is perfectly rational on the part of the firms and results in positive profits for the competing firms.

Given this theoretical equilibrium we predict prices that end in 9 to be maintained longer than any other price-endings. Furthermore, even though theory would not predict price-endings different from 99 in equilibrium ${ }^{2}$ it predicts similar demand for such items as long as they are priced with the same euro digit.

A different explanation for the level effect is mentioned already by Monroe (1973). The hypothesis postulates that consumers, when they plan to purchase an item, have already formed an expectation of the price they are going to pay, a so-called target price. ${ }^{3}$ If such a target price is memorized with as has been shown in Christie and Schultz (1994) and Christie et al. (1994).

${ }^{2}$ Basu (2006), establishes an equilibrium in 99 cent prices; a further result shows the existence of two equilibria, one with 99 cent, the other with marginal cost.

${ }^{3}$ In a similar version of the story consumers might have binding budget set, because they have only one or two cash bills with them and while a price just below this threshold lies 
an even number, it would typically be beneficial to set prices below these even-numbered thresholds. As this explanation is usually seen observationally equivalent to the boundedly rational behavior we do not discriminate between the two explanations any longer.

(ii) The other important consumer-based approach is called image effect (Stiving and Winer (1997), Thomas and Morwitz (2007) or Schindler (1991)): Price setters may use the pattern of a price to transmit specific information about the item that is being offered. An example could be a clothing company that uses 00c endings in regular times and 99 endings for items on sale. If this was true and a 9-ending communicated a good bargain, we would also expect price clustering, higher demand and maybe some rigidity on 9-ending prices. Yet, not all the prices are predicted to end in 9 and a similar pattern might emerge for prices ending in 0 (or any other special number), if a zero were to transmit positive properties such as product quality. ${ }^{4}$

It should be noted that the 'image effect' theories predict higher demand at focal prices, whereas the 'level effect' predicts that consumers do not react to differences in the cent digits with their demand behavior. Moreover, 'image effects' might be prevalent not only in 99-ending prices, but also in even prices. In terms of price stability Basu (2006) predicts that 99-ending prices are more stable; in particular they should not be underbid by the rivals. There is no clear prediction for the equilibrium on part of the 'image effect' theory, because shop behavior is not explicitly modeled: image prices could be less stable, because rivals might want to destroy the image of a cheap price by simply underbidding it; on the other hand, they might be more stable if the additional demand at the image price is so high, that changes are not worthwhile.

\subsection{Empirical Evidence}

Concerning demand effects of focal prices, there is a large experimental literature - starting already in 1936 by Ginzberg (1936) - but only a few studies look at real markets and actual demand on a larger scale. In one larger study on single products Stiving and Winer (1997) use scanner data on yoghurt and tuna and find a large and generally positive relationship between a 9-ending

within their budget set, a price just above doesn't.

${ }^{4}$ See also Palmon et al. (2004) for a survey. 
price and sales. Moreover, they find, that consumers don't process prices holistically. The field experiments by Schindler and Kibarian (1996) and Anderson and Simester (2003) observe demand for items in a mail-order catalogue, where prices were manipulated to show 9-endings. Generally, these experiments find an overall positive effect on demand. Yet, the significance of the effect depends on a variety of other factors, such as how much information was available on a product and whether the item has been introduced only recently. Laboratory experiments, in general, have to rely on purchase intentions instead of actual demand. An example of such an experiment is Gendall et al. (1997), suggesting that 9 -ending prices affect purchase intentions positively. ${ }^{5}$

Studies looking at price rigidity are very rare. ${ }^{6}$ Levy et al. (2007) find evidence that prices ending in nines are sticky in the sense that price setters are more reluctant to change them. Once these price is changed, though, the ultimate price jump is larger which might be due to a larger adjustment need. Sehity et al. (2005) were using the introduction of the euro showing that retailers all across Europe quickly converged to focal prices again, which had been overturned on the first of January, 2002.

Only a few studies are able to differentiate between level-effects (left-digit effect) or image effects. The aforementioned study by Stiving and Winer (1997) found, that consumers treat the pre-, and post-comma digits in a different manner. However, apart from this study, the evidence on the image-effect stems from lab experiments and surveys. In an intention-to-purchase experiment Liang and Kanetkar (2006) obtain similar results as Stiving and Winer (1997). However, both studies report that even pricing plays a role as well, which they tend to take as evidence for image effects. Using experimental evidence from Italian consumers Guido and Peluso (2004) find evidence for even target prices. Moreover, when analyzing how prices are memorized, they find that consumers recall odd prices smaller than they really are, especially when the leftmost digit is manipulated in the experiment. ${ }^{7}$ Thomas and Morwitz

\footnotetext{
${ }^{5}$ Liang and Kanetkar (2006) provide an extensive review of the existing literature on price endings and discuss also the literature on numerical processing and memory-effects of odd prices; Kauffman and Lee (2005) review issues of price rigidity in e-commerce in general.

${ }^{6}$ Macroeconomists look at price points or reference prices when they inquire the existence or prevalence of nominal price rigidities; e.g. Eichenbaum et al. (2008), Levy et al. (2007) or Konieczny and Rumler (2006). 9-ending prices can act as price points and might in such a way contribute to price stickiness in general.

${ }^{7}$ See also Guéguen and Legoherel (2004).
} 
(2005) finally conclude that the scale of level effects depends on which digit to the left is affected, which is an indication that left-digit-effects play a role.

Specific evidence for image effects is provided by Naipaul and Parsa (2001), who compare restaurant menus and find that menu-makers use even prices to suggest higher quality and just-below prices to indicate bargains. This is largely in line with the ideas in the work of Schindler (1991).

\section{$3 \quad$ Data and prevalence of price points}

For our empirical analysis we use the database of http://www.geizhals.at. This web site is a price search engine collecting the price offers via standardized protocols from retailers and presents them electronically via its web-platform. Due to the broad Austrian market penetration of Geizhals.at, this price search engine practically covers the whole Austrian online market including suppliers from other countries (especially Germany) which are interested in the Austrian e-commerce business.

We use an inflow sample of all price spells starting in an arbitrary week in $2007^{8}$. A price spell is defined as the offer from a specific firm $j$ for a specific good $i$ at a specific price $p_{i j}$. Each spell has a starting and ending time so that we can exactly measure the spell durations in seconds. Price spells end because firms change their price or stop offering the product. Additionally we know for each and every price spell the respective referral requests from customers. Referral requests are customer clicks on the firm's product offer at the Geizhals.at web page resulting in a forward from the web site of the price search engine to the online shop of an e-tailer. We normalize the referral requests to clicks per day to cope with the different offer durations. As very cheap products are not expected to be bought online due to relatively high shipping cost we keep only those product offers with an average price larger than $€ 25$. Purchases below that threshold are atypical in e-commerce and unlikely to occur outside bundles. In total we have 818,483 price spells for 714 e-tailers and 24473 products. On average we measure 25.5 referral requests per day and product. A more detailed description of our dataset can be found in Table 1.

\footnotetext{
${ }^{8}$ Monday, June 4, 2007, 03:00:00 to Monday, June 11, 2007, 03:00:00.
} 
Due to the multi-faceted structure of the data we have control variables at three different levels (descriptives on the variables of interest can be found in Table 1: (i) E-tailer specific variables - being constant for the product offers of a specific web-shop $j$ - are the (a) country of origin, (b) a dummy variable, indicating whether the firm disposes of a pick up facility for customers who want to avoid the cost and time it takes to ship an item. (c) Finally, we observe all quality reviews of previous customers. They consist of a free text section and a standardized grading scheme (five grade scale: $1 \ldots$ best, $5 \ldots$ worst). We use this information to construct the average grade as a variable that captures perceived service quality of shops. (d) Moreover, we can control for the number of customers' evaluations.

(ii) Furthermore, we have information on three product specific controls: (a) The number of competing shops measures how many shops were active in the market $i$ and is thus a measure of competition. (b) activity in the market: We generated this variable by counting the number of price changes that were observed during the week of observation to control for the general turbulence in the market $i$. (c) a quality indicator for the product. Customers have the possibility to recommend the product on the Geizhals.at website for purchase or not. Out of these valuations we know the percentage of positive recommendations for the product.

(iii) Apart from price, referral clicks and the timestamps (begin and end) of a price spell, we observe the following offer-specific ( $i j$ ) information: (a) shipping cost and (b) time until the product is can be shipped. If some control variables (mostly availability, shipping-cost and pick-up facility and product reviews) were not available, we imputed those variables at the mean and used imputed variables together with a missing flag for imputations.

Even though referral clicks are available in the data, the actual act of purchasing a product is unknown, because actual purchases happen at the e-tailer's own web site. This is unobservable for Geizhals.at and thus for us. Therefore, following Smith and Brynjolfsson (2001) and Bai (2004), we use the concept of last-click-through (LCT) as a proxy for the purchasing decision. If a customer is searching for a product, she might meander around different web sites, comparing characteristics of the shops, but she will finally settle for the preferred shop and buy there online. The last click to a shop selling the product is usually identified as the click with the highest purchase probability. We con- 
struct the LCT from the referral clicks using a procedure which is based on hierarchical clustering and Grubbs' test for outlier detection. ${ }^{9}$

Figure 1 shows the frequency distribution of price-endings to check for the prevalence of price points. The four graphs depict the distribution of price endings in different samples of interest: (a) all prices, (b) offers that were clicked at least once, (c) price-leading offers and (d) best-selling offers (defined as most frequently clicked offers with a market share greater than $10 \%)^{10}$. Note that in any of the four samples odd and even prices are more frequent and that even prices are even more so. Given that we observe 100 different cent-endings, a uniform distribution would imply a frequency of 1 percent of the observations for each digit. Clearly the 00c, 99c, 90c, and 50c-ending are more frequent than other price endings. This pattern is even more pronounced, when we restrict our attention to price-leading or best-selling offers. Almost $4 \%$ of the price-leading offers (fourfold the expected frequency) were quoted in $99 \mathrm{c}$ and another $4 \%$ were quoted in 90c. Taken together, the four focal price endings make up more than $40 \%$ of the bestselling price-endings.

Prices ending at even euro might be more relevant for expensive products. A closer look at the 00 cent digits reveals that these prices are not necessarily typical 'even prices'. Figure 2 shows the distribution of the unit position for prices ending with 00 cent. The four graphs show the same four groups of interest we used above. It turns out that in all groups a cumulation of prices ending in 9 can be observed - and as before, the pattern is even more pronounced for the clicked and best-selling offers. E.g. in the sample of bestprice offers 40 percent of offers end with nine euro, zero cent.

\section{Price points and consumer behavior}

Our demand estimation in Table 2 looks at consumers' clicks $\left(q_{i j}\right)$ on the 'Geizhals'-website. A consumer click is a referral request to retailer $j$ for product $i$.

\footnotetext{
${ }^{9}$ In practice, the construction of the last-click-through (LCT) is a lengthy procedure because a time span for observation as well a product span has to be chosen. See Dulleck et al. (2008) for details. Here, we define LCTs on the product level where a time interval of one week initiates a new search period. Additional results when using other definitions of $\mathrm{LCT}$ are available upon request.

${ }^{10}$ Market share was defined as the number of referral requests for offer ij relative to the total number on clicks on product $\mathrm{j}$.
} 


$$
q_{i j}=a_{0}+b D_{i j}+a_{1} \text { rel.price } \text { prj }_{i j}+c X_{i j}+a_{2 i} \text { product }_{i}+\epsilon_{i j}
$$

As the duration of the price offers varies, we standardize consumer clicks as the number of clicks per week. The vector $D_{i j}$ includes various dummy variables for price points, like odd or even prices. We use two different definitions for price points:

In the first definition we use the most frequent price points as dummy variables: cent prices ending in 99c $(€ 0.99), 90 \mathrm{c}(€ 0.90)$ and 50c $(€ 0.50)$. For prices with zero cent we distinguish those with a nine before the comma (€9.00) from those with other digits ( $€ \neg 9.00)$ because the former should be considered as 9-ending prices.

To convey the flavor of odd and even prices we use a second - more encompassing - definition. We set the dummy 9-clustered to 1 if the price is either ending with 9 neglecting the rightmost zeros (e. g. $€ 576.90, € 39.00, € 590.00$ ) or has at least one nine in the last four digits including the cent (e.g. €91.81, €899.11, $€ 59.92$ ). The dummy evenprice(without9) takes the value 1 whenever a price's ending is 00 cent without a nine being present in the four rightmost digits (e. g. $€ 345.00, € 100.00)$. This definition for 9-clustered prices is broader and covers also prices which at first sight might not be considered as focal prices; the advantage of the definition is that it is a general one and not ad-hoc.

Finally, to test directly Basu (2006) we artificially split up the price into its euro digits (multiplied by 100) and the remaining cent digits. Fully rational consumers should pay the same attention to changes in the euro or the cent digits, provided they have the same amount; the coefficients for the two variables should be equal and negative. Basu (2006) on the other hand, argues that consumers do not consider the cent digits in their demand, its coefficient should be zero therefore.

The variable rel. price measures the price of product $i$ of retailer $j$ relative to the average price of product $i$ over all retailers (hence rel. price $e_{i j}=\frac{p_{i j}}{\sum_{j=1}^{N} p_{i j} / N}$ ). Additional control variables in vector $X$ include: rel. shipping cost which are calculated from the information given at Geizhals.at. Germany is equal to 1 if the online shop is located in Germany, Austria otherwise. Avail is equal to 1 if the product is deliverable at short notice. Evaluation - grade measures the service and reliability evaluation of a shop $j$ by the costumers 
in a scale between 1 and 5 (very good to very bad). \#Evaluations counts the number of customers who have given an evaluation of the retailers' service characteristics. Pickup is equal to 1 if the retailer has a pick up store. As we are merging markets for different products, we include product fixed effects in the estimation. We are using price offers for a week in June 2007. As prices may be valid for a varying number of days, we calculate a standardized number of clicks per day as our dependent variable $q_{i j}$.

Price setting might be endogenous to demand. Therefore, we instrument the relative price of the product by the mean relative price a firm has in all markets except in markets where the products belong to the same subsubcategory as the product in question ${ }^{11}$. In the first stage regression, the instrument has a strong and significant impact on prices resulting in a marginal $R^{2}$ of 0.093 . Moreover, setting a low price in a different market should not influence demand in our market; thus the exclusion restriction will hold. The exclusion restriction is particularly convincing, because customers in a price-comparison site cannot look at the complete price list for all products in the other subsubcategories of one particular firm. As the organization of the web-site allows only price comparisons for one particular product across firms, consumers have a very hard time to get an image of the overall pricing behavior of one particular firm.

Table 2 looks at the influence of price points on demand using customer clicks. columns (1) to (3) of Table 2 use all referral requests as demand indicators, whereas columns (4) to (6) employ only last-click-throughs (LCTs) which are considered as better indications for real purchasing decisions. Both indicators for demand give fairly similar results: as expected, those on last-click-throughs are numerically considerably smaller.

There is no clear indication that the usage of price points (column 1) boosts demand. Prices ending with 99 cent are unremarkable. Whereas prices ending with 90 or 50 cent attract less clicks, those ending with zero cent - in particular those ending with 9 euro - attract more clicks. Regression results for the lastclick-throughs in column (4) confirm this picture, albeit on a lower scale. This pattern is generally affirmed using our definitions for odd and even prices in

\footnotetext{
${ }^{11}$ Geizhals.at maps products hierachically into subsubcategories, subcategories and categories describing the substitutional relationship between the products. As an example, the category 'Video/Photo/TV' contains the subcategory 'TV sets' and the subsubcategory '30-39 inch LCD TV sets'. In total 358 subsubcategories and 40 subcategories are given.
} 
column (2): we receive somewhat higher demand for 9-clustered price endings, but no effects for even prices not containing nines. The relatively small effect of 9-clustered prices vanishes once we introduce last-click-throughs in column (5).

Finally, our test for left-to-right processing: Contrary to a fully rational consumer our shoppers behave only boundedly rational. The euro part of the price has a strong negative effect on demand, whereas the effect of the cent is either positive for the number of clicks or zero for LCTs. This is a direct affirmation of Basu's (2006) hypothesis of consumers disregarding the cent. For more expensive products not only cent but also unit digits should be irrelevant for the consumer decision. For products with prices above $€ 100$ we repeated this exercise, but shifted one digit to the left: a price of $€ 234.67$ results so in a 'significant variable' with a value of 23.000 and an 'insignificant variable' with value 0.467 . Again, rational consumers should show the same coefficients for both variables. For all clicks we find coefficients of $-0.028^{* * *}$ (0.002) for the first and $0.376^{* * *}(0.081)$ for the second variable, for LCTs we find $-0.002^{* * *}(0.0002)$ and $0.034^{* * *}(0.010)$. These patterns with the nonnegative signs for the 'insignificant variable' strongly confirm Basu's bounded rationality hypothesis.

Our further control variables meet our expectations from online markets: The relative price of the shop decreases demand. ${ }^{12}$ The positive influence of higher shipping cost on market demand can be seen as evidence for obfuscation strategies, where online shops compensate their lower prices with higher extra charges. 13

E-tailers with immediately available offers and better and more customer evaluations attract more customers. The positive sign of the Germany dummy points out that the Austrian price search engine is increasingly used by the German market ${ }^{14}$.

\footnotetext{
${ }^{12}$ This effect is not statistically significant in the LCT model, which might be due to the instrumentation strategy. The corresponding OLS coefficients for the relative price are both significant and somewhat higher than the ones presented in Table 2.

${ }^{13}$ Hossain and Morgan (2006) show that buyers are inattentive to shipping costs in eBay auctions as well.

${ }^{14}$ In November 200872 percent of the online shops are located in Germany and 62 percent of the clicks are from German IP-addresses.
} 


\section{$5 \quad$ Price rigidity and firm behavior}

In this section we analyze the relationship between price endings and the duration of price-quotes. If 99-ending prices are an equilibrium maximizing firms have a low inducement to change these price points. On the other hand, if a price ending is non-focal e-tailers should have an incentive to switch to a nearby price point to increase demand. Hence, price point theory predicts that shops maintain offers at price points significantly longer than non-focal prices.

We use duration analysis to compare the survival time of offers with price points to the other offers' survival time. At first, we look at individual firm behavior as it is measured by the time span that elapses until a firm changes its own price. We model the hazard of ending an individual spell at duration $t$ using a semi-parametric Cox model which allows for a fully flexible baseline hazard $h_{j 0}(t)$ and adds other variables proportionally:

$$
h\left(t \mid j, D_{i j}, \theta_{i j}, x_{i}\right)=h_{j 0}(t) \exp \left(\delta D_{i j}+\beta x_{i}+\gamma \theta_{i j}\right)
$$

$j$ is the firm index and $i$ is the product-index. The variables of interest are the indicators for the respective price endings $€ 0.99, € 0.90, € 0.50, € 9.00$, $€ \neg 9.00$, 9-clustered, and evenprice(without9). Additionally, we add controls at the offer-level and the product-level ${ }^{15}: \theta_{i j}$ are four offer-specific controls, which include shipping cost, availability, clicks and price. $x_{i}$ captures three product-invariant characteristics such as number of competing shops, activity in the market in form of the number of price changes and an indicator for recommendations of the product by consumers. ${ }^{16}$

\subsection{Pooled analysis}

We first present in Table 3 (column 1-3) results from a pooled analysis where the baseline hazard $h_{j 0}(t)$ is assumed to be equal for all firms. (i.e.: $h_{j 0}(t)=$ $\left.h_{0}(t) \forall j\right)$. Standard errors are clustered at the product level. The base regression in column (1) uses no additional control variables and thus corresponds to

\footnotetext{
${ }^{15}$ Since we later stratify with respect to shops there is no need to add shop-specific controls.

${ }^{16}$ Kauffman and Lee (2005) discuss hypotheses about price rigidity in e-tailing relating to market concentration, product quality and size of the market. Kashyap (1995) gives a comprehensive overview of price stickiness in retail (catalogs).
} 
estimating simple Kaplan-Meier survivor functions for the five different price points $€ 0.99$, €0.90, $€ 0.50, € 9.00$, and $€ \neg 9.00$. All offers with price points have a lower hazard; i.e. they last longer. The effect is strongest for the odd price endings $€ 9.00$ followed by $€ \neg 9.00$ and $€ 0.99$. We see the lowest impact for $€ 0.50$. A Coefficient of -0.762 for $€ 9.00$ corresponds to a reduction of $53.32 \%$ in the hazard rate. Likewise, a coefficient of -0.238 for the $50 \mathrm{c}$ dummy translates to a reduction of $21.18 \%$. When a non-focal price ending has a $50 \%$ chance of surviving 54 hours, an offer that is priced in $50 \mathrm{c}$ has a $58 \%$-chance to make it to the same point in time. A 90c-offer's odds to survive 54 hours or more are $72 \%$.

When adding control variables in column (2) we see our results basically unchanged: both the numerical values as well as the ranking of coefficients for our price points are fairly stable. Although there are no strict theoretical predictions for our control variables the coefficients fit into a reasonable picture: More expensive articles and offers with higher shipping cost tend to have longer offers. The fact that offers for products which are immediately available hold longer is consistent with an obfuscation strategy: e-tailers which do not have the product in stock might use short-run bargain offers in order to attract the customers' attention. At a later point in time - when the product can be delivered immediately - they switch to a higher price. The more clicks an offer generates the lower is the incentive to change the price. The same applies for a low number of average price changes from all other firms on the market, which is an indicator for the market's intensity of competition.

Column (3) uses the alternative specification of price points. Again, price points have significant and substantial longer durations than other prices: here, the highest effect is for even price (without 9), with a somewhat smaller effect for the 9-clustered dummy.

\subsection{Stratified analysis}

It might be that particular shops have specific pricing strategies: e.g. one shop is changing prices routinely each week, another firm might change them every day. In order to deal with these differences, we use a stratified analysis, which is allowing for a firm-specific baseline hazard rate. Our identification of the effect of price points stems now only from within-firm variation in the duration 
of price offers. As in any fixed-effects model we would expect lower coefficients in this stratified analysis.

In columns (4-6) of Table 3 we report results from the stratified estimation, again including product-specific clustered error terms. While, as expected, our numerical coefficients are smaller as compared to the pooled analysis, all the previous patterns are reinforced. Focal prices have a longer average duration and the effect is strongest for prices ending in $€ 9.00$ and even price (without 9) prices. Again, the weakest effect is found for price quotes ending in 50c. This stratified analysis shows that our price point effects cannot be explained by firm-specific pricing policies: even one and the same shop keeps offers with price points longer than other comparable offers.

\section{Price rigidity for price leaders}

Up to now we looked at the stability of any price offers. To investigate market outcomes or equilibrium outcomes, the equilibrium price should be studied. As there is still price dispersion in online markets we take the offer with the lowest price: the "price-leading" offer. We thus draw a sub-sample of offers, which held the lowest price at one point in time. The time a price-leading offer is valid can be cut in different ways: either another firm is actively undercutting this price or the price-leading firm itself is discontinuing the offer by going out of the market or charging a higher price. For an analysis of the competitive actions in such a market, undercutting by rivals is the decisive feature. Basu (2006) would argue that an equilibrium at 99-cent prices would not be undercut by a rival because it is not profitable to do so.

The new sample consists of 41574 offers and 14928 incidents, where a priceleading offer was undercut by an opponent. Our analysis uses a competing risk Cox model stratified by firm level in order to allow for two outcomes: underbidding or own price changes. Table 4 shows the results. columns (1-3) show top-offers, which ended by undercutting while columns (4-6) show top offers that were changed by the price-leader itself. We use the same specifications as in Table 3. Our main interest is in the undercutting part. Focal prices are less likely to be undercut, the strongest effect is for prices ending in $€ 9.00$

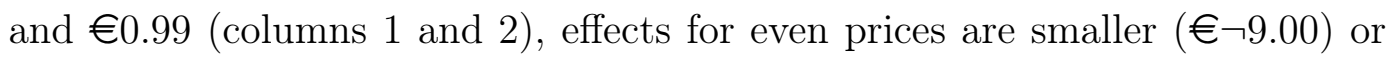
insignificant $(€ 0.50)$. When we use our alternative specification (column 3 ) we 
see a similar pattern: a strong effect for odd prices, but no significant effect for even prices (evenprice(without9)). The results for own changes in columns (4) to (6) are less clear: only prices ending in 90 cent live longer before they are withdrawn by the firms.

Controls in Table 4 show basically a consistent picture: The higher the number of clicks while in lead the higher is the probability that the offer is undercut by a competitor. The more active a market is - measured with the number of price changes of all other firms - the shorter are the best-price price spells. In markets with a higher number of competing shops we observe that shops change their prices more frequently.

\section{$7 \quad$ Interpretation and conclusions}

In this paper we present the first comprehensive and consistent analysis of price points on the supply and demand side of a market. We analyze the issue in the context of e-commerce, an environment that is, a priori, not very favorable to price points. Our results are consistent with Basu (2006) who assumes boundedly rational shoppers ignoring the rightmost digits due to limited processing capacity. Profit-maximizing firms will adapt by setting prices ending in $9 \mathrm{~s}$. We find that market demand does not react to differences in the cent digits, as Basu (2006) is assuming. Moreover, odd prices show typical equilibrium characteristics: they are more sticky than regular or even prices. This is particularly so for best-price offers: when these offers end with 9, they are less likely to be undercut by the rivals, they are also less often changed by the firm itself.

\section{References}

Anderson, E.T. and D.I. Simester (2003), 'Effects of $\$ 9$ price endings on retail sales: Evidence from field experiments', Quantitative Marketing and Economics 1(1), 93-110.

Bai, Xue (2004), Why pay more? why charge less? Heinz School of Public Policy and Management, Carnegie Mellon University, Pittsburgh, Working Paper.

Basu, K. (2006), 'Consumer Cognition and Pricing in the Nines in Oligopolistic Markets', Journal of Economics 83 Management Strategy 15(1), 125-141. 
Brynjolfsson, Erik and Michael Smith (2000), 'Frictionless commerce? a comparison of internet and conventional retailers', Management Science 46(4), 563-585.

Christie, W.G., J.H. Harris and P.H. Schultz (1994), 'Why did NASDAQ market makers stop avoiding odd-eighth quotes?', Journal of Finance 49(5), 1841-1860.

Christie, W.G. and P.H. Schultz (1994), 'Why do NASDAQ market makers avoid odd-eighth quotes?', Journal of Finance 49(5), 1813-1840.

Dulleck, Uwe, Franz Hackl, Bernhard Weiss and Rudolf Winter-Ebmer (2008), Buying online: Sequential decision making by shopbot visitors. University of Linz, mimeo.

Eichenbaum, Martin, Nir Jaimovich and Sergio Tavares Rebelo (2008), Reference Prices and Nominal Rigidities. NBER Working Paper, Number 13829.

Gendall, P., J. Holdershaw and R. Garland (1997), 'The effect of odd pricing on demand', European Journal of Marketing 31(11/12), 799-813.

Ginzberg, E. (1936), 'Customary prices', The American Economic Review 26, 296-296.

Guéguen, N. and P. Legoherel (2004), 'Numerical encoding and odd-ending prices', European Journal of Marketing 38(1/2), 194-208.

Guido, G. and A. Peluso (2004), 'Consumers'perception of odd-ending prices with the introduction of the Euro', Journal of Product and Brand Management 13, 200-210.

Hossain, Tanjim and John Morgan (2006), '... plus shipping and handling: Revenue (non) equivalence in field experiments on ebay', Advances in Economic Analysis and Policy 6/2/3.

Kashyap, Anil K. (1995), 'Sticky prices: New evidence from retail catalogs', Quarterly Journal of Econmics 110(1), 245-274.

Kauffman, Robert J and D. Lee (2005), Should we expect less price rigidity in the digital economy? MIS, Carlson School of Management, University of Minnesota.

Konieczny, Jerzy (Jurek) D. and Fabio Rumler (2006), Regular adjustment theory and practice, Working Paper Series 669, European Central Bank.

URL: http://ideas.repec.org/p/ecb/ecbwps/20060669.html

Levy, D., D. Lee, H.A. Chen, R.J. Kauffman and M. Bergen (2007), 'Price Points and Price Rigidity', Munich Personal RePEc Archive .

URL: http://mpra.ub.uni-muenchen.de/1472/1/MPRA_paper_1472.pdf 
Liang, J. and V. Kanetkar (2006), 'Price endings: magic and math', Journal of Product \& Brand Management 15(6), 377-385.

Monroe, K.B. (1973), 'Buyers'subjective perceptions of price', Journal of Marketing Research 10(1), 70-80.

Naipaul, S. and HG Parsa (2001), 'Menu Price Endings that Communicate Value and Quality', Cornell Hotel and Restaurant Administration Quarterly 42(1), 26.

Palmon, O., B.A. Smith and B.J. Sopranzetti (2004), 'Clustering in real estate prices: determinants and consequences', Journal of Real Estate Research $\mathbf{2 6}(2)$.

Schindler, R.M. (1991), 'Symbolic meanings of a price ending', Advances in Consumer Research 18, 794-801.

Schindler, R.M. and T.M. Kibarian (1996), 'Increased consumer sales response though use of 99-ending prices', Journal of Retailing 72(2), 187-199.

Sehity, T., E. Hoelzl and E. Kirchler (2005), 'Price developments after a nominal shock: Benford's Law and psychological pricing after the euro introduction', International Journal of Research in Marketing 22(4), 471-480.

Smith, Michael D. and Erik Brynjolfsson (2001), 'Consumer decision-making at an internet shopbot: Brand still matters', Journal of Industrial Economics 49(4), 541-558.

Stiving, M. and R.S. Winer (1997), 'An empirical analysis of price endings with scanner data', Journal of Consumer Research 24(1), 57-67.

Thomas, M. and V. Morwitz (2005), 'Penny wise and pound foolish: the leftdigit effect in price cognition', Journal of Consumer Research 32(1), 54-64.

Thomas, M. and V. Morwitz (2007), Heuristics in Numerical Cognition: Implications for Pricing. Handbook of Research in Pricing, Edward Elgar, forthcoming; Johnson School Research Paper Series No. 1-08. 


\section{Tables and Graphs}

Figure 1: Distribution of the cent digits on www.geizhals.at
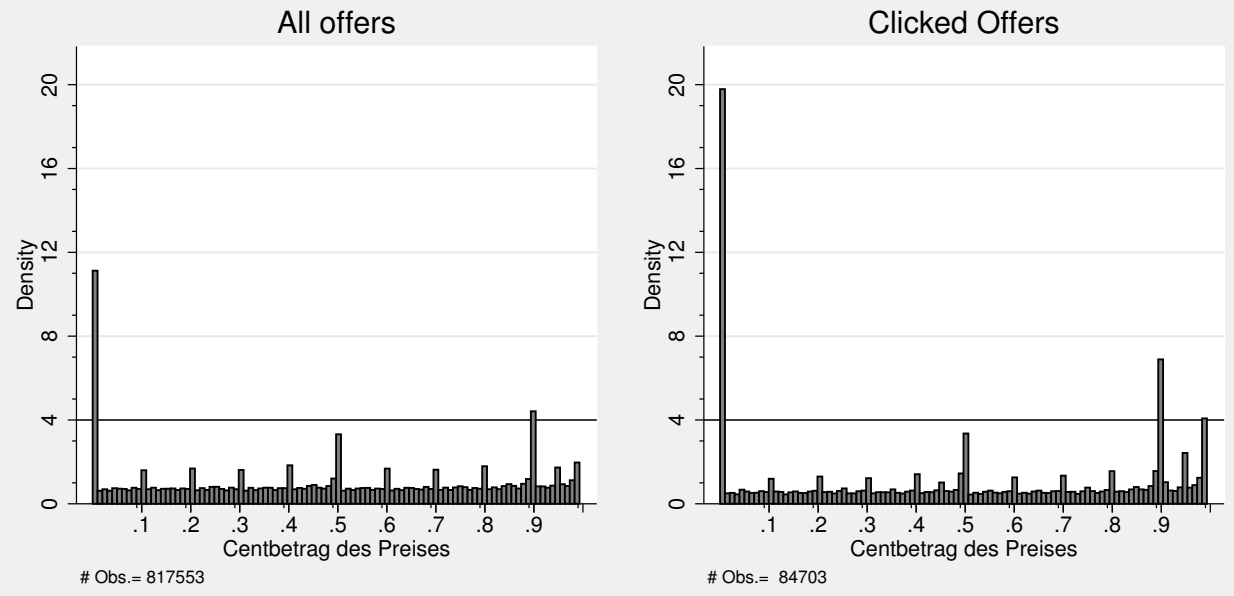

Priceleaders

Bestsellers
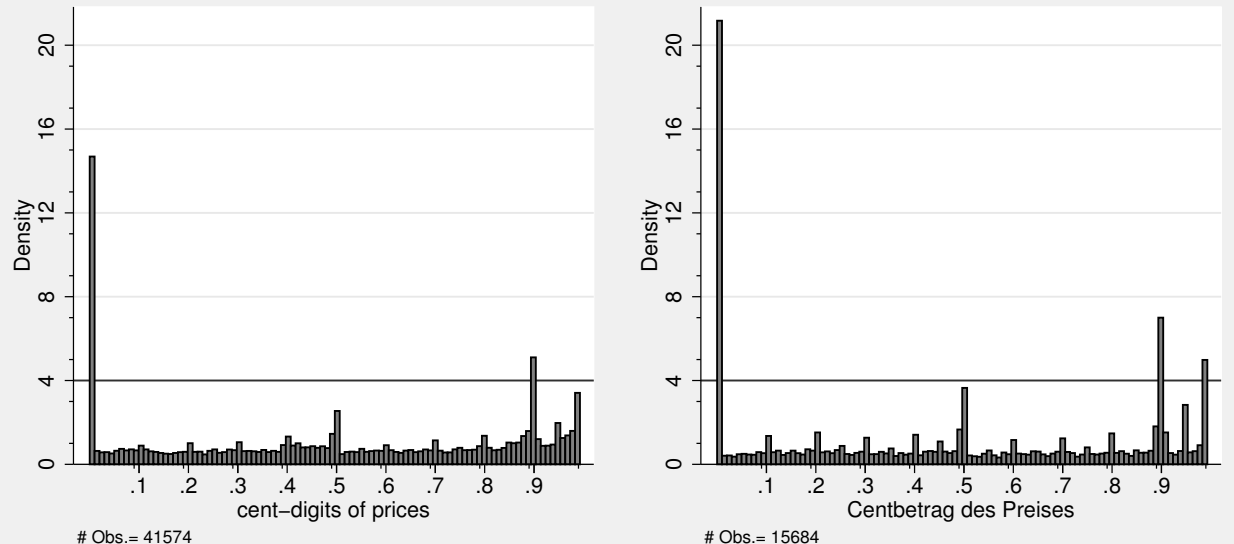

Notes: No. observations: 817,553 (84,703 clicked offers, 41,574 priceleaders and 15,684 bestsellers) 
Figure 2: Distribution of the last euro digits of 00c-ending offers on www.geizhals.at
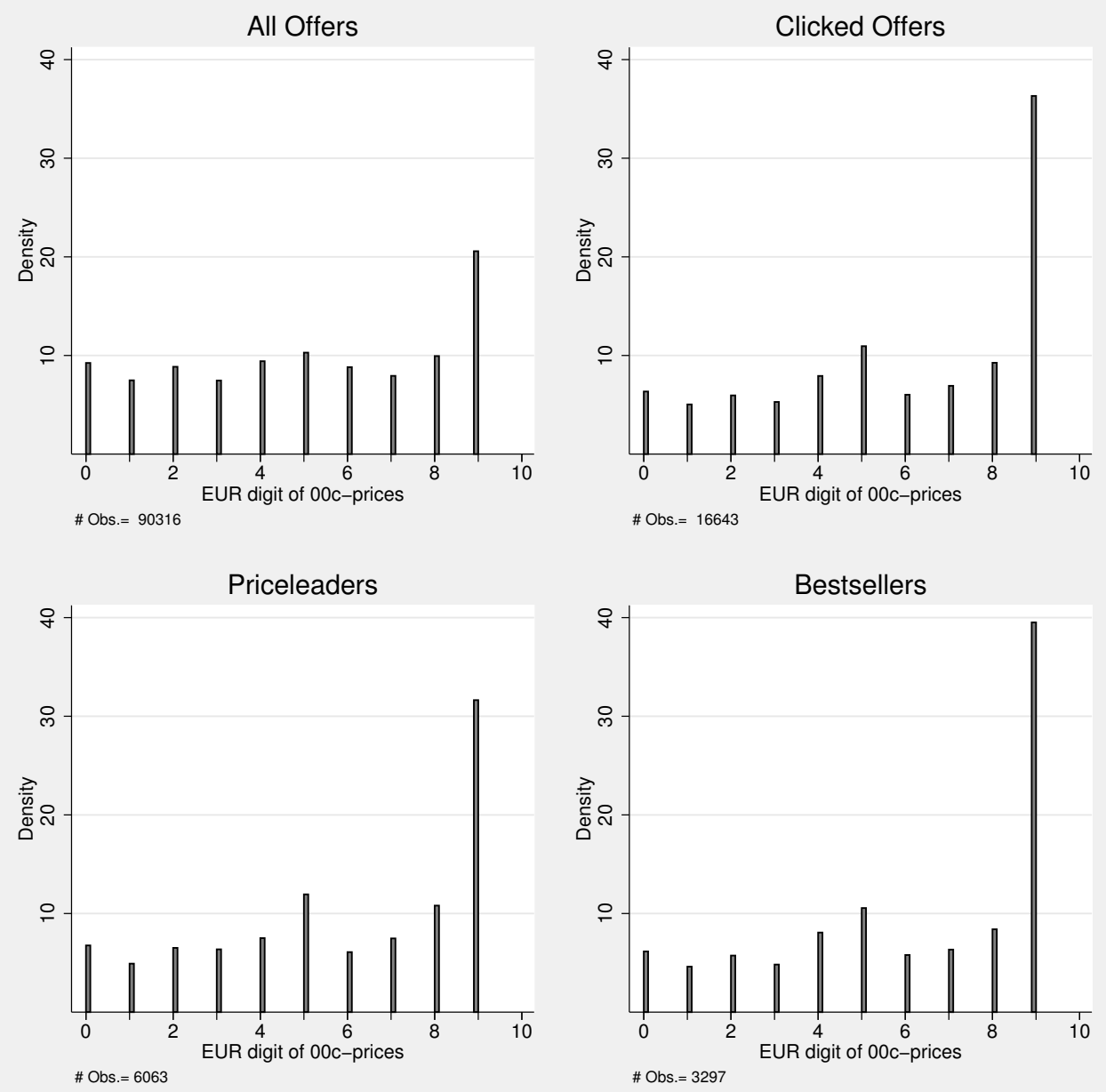

Notes: No. observations: 90,316 (16,643 clicked offers, 6,063 priceleaders and 3,297 bestsellers) 


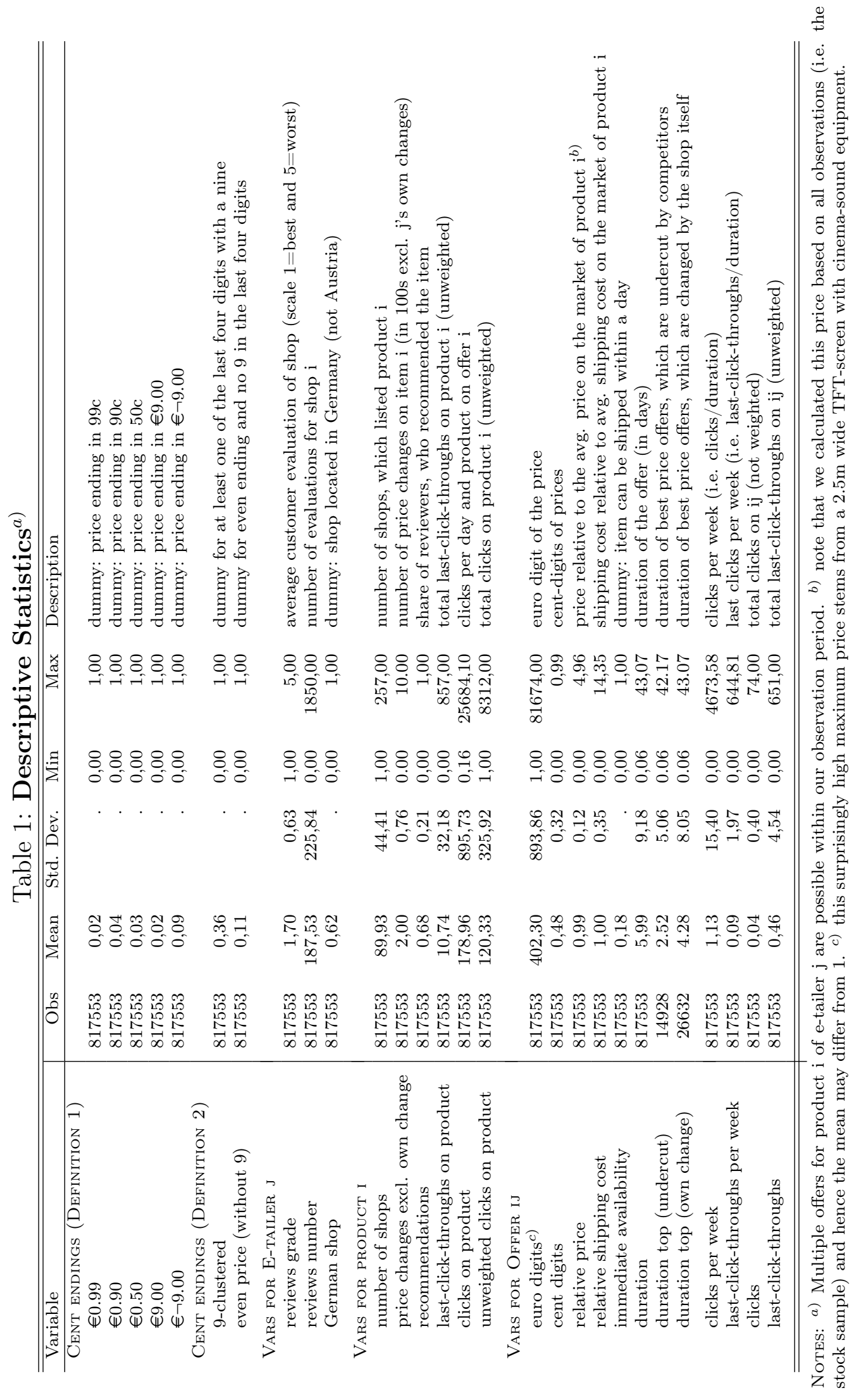


Table 2: Demand and Focal Pricing

\begin{tabular}{|c|c|c|c|c|c|c|}
\hline & \multicolumn{3}{|c|}{ clicks per week } & \multicolumn{3}{|c|}{ last-click-throughs per week } \\
\hline & (1) & $(2)$ & (3) & $(4)$ & $(5)$ & (6) \\
\hline$€ 0.99$ & $\begin{array}{c}0.097 \\
(0.121)\end{array}$ & & & $\begin{array}{l}-0.020 \\
(0.016)\end{array}$ & & \\
\hline$€ 0.90$ & $\begin{array}{c}-0.276^{* * *} \\
(0.082)\end{array}$ & & & $\begin{array}{l}-0.018^{*} \\
(0.011)\end{array}$ & & \\
\hline$€ 0.50$ & $\begin{array}{c}-0.614^{* * *} \\
(0.094)\end{array}$ & & & $\begin{array}{c}-0.050^{* * *} \\
(0.012)\end{array}$ & & \\
\hline$€ 9.00$ & $\begin{array}{c}0.510^{* * *} \\
(0.119)\end{array}$ & & & $\begin{array}{c}0.065^{* * *} \\
(0.016)\end{array}$ & & \\
\hline$€ \neg 9.00$ & $\begin{array}{c}0.266^{* * *} \\
(0.061)\end{array}$ & & & $\begin{array}{c}0.023^{* * *} \\
(0.008)\end{array}$ & & \\
\hline 9-clustered & & $\begin{array}{c}0.087^{* *} \\
(0.037)\end{array}$ & & & $\begin{array}{c}0.006 \\
(0.005)\end{array}$ & \\
\hline even price (without 9) & & $\begin{array}{c}0.058 \\
(0.057)\end{array}$ & & & $\begin{array}{c}0.005 \\
(0.008)\end{array}$ & \\
\hline euro digits in $100 \mathrm{~s}$ & & & $\begin{array}{c}-0.307^{* * *} \\
(0.018)\end{array}$ & & & $\begin{array}{c}-0.021^{* * *} \\
(0.002)\end{array}$ \\
\hline cent digits & & & $\begin{array}{c}0.131^{* *} \\
(0.052)\end{array}$ & & & $\begin{array}{c}0.003 \\
(0.007)\end{array}$ \\
\hline relative price & $\begin{array}{c}-1.516^{* * *} \\
(0.425)\end{array}$ & $\begin{array}{c}-1.585^{* * *} \\
(0.424)\end{array}$ & & $\begin{array}{l}-0.051 \\
(0.056)\end{array}$ & $\begin{array}{l}-0.055 \\
(0.056)\end{array}$ & \\
\hline rel. shipping cost & $\begin{array}{c}0.180^{* * * *} \\
(0.051)\end{array}$ & $\begin{array}{c}0.200^{* * *} \\
(0.050)\end{array}$ & $\begin{array}{c}0.180^{* * *} \\
(0.050)\end{array}$ & $\begin{array}{c}0.017^{* *} \\
(0.007)\end{array}$ & $\begin{array}{c}0.019^{* * *} \\
(0.007)\end{array}$ & $\begin{array}{c}0.017^{* *} \\
(0.007)\end{array}$ \\
\hline $\begin{array}{l}\text { immmediate } \\
\text { availability }\end{array}$ & $\begin{array}{c}1.683^{* * *} \\
(0.049)\end{array}$ & $\begin{array}{c}1.664^{* * *} \\
(0.048)\end{array}$ & $\begin{array}{c}1.691^{* * *} \\
(0.047)\end{array}$ & $\begin{array}{c}0.152^{* * *} \\
(0.006)\end{array}$ & $\begin{array}{c}0.150^{* * *} \\
(0.006)\end{array}$ & $\begin{array}{c}0.151^{* * *} \\
(0.006)\end{array}$ \\
\hline $\begin{array}{l}\text { reviews } \\
\text { grade }\end{array}$ & $\begin{array}{c}-0.105^{* * *} \\
(0.028)\end{array}$ & $\begin{array}{c}-0.113^{* * *} \\
(0.028)\end{array}$ & $\begin{array}{c}-0.104^{* * *} \\
(0.028)\end{array}$ & $\begin{array}{c}-0.011^{* * *} \\
(0.004)\end{array}$ & $\begin{array}{c}-0.012^{* * *} \\
(0.004)\end{array}$ & $\begin{array}{c}-0.012^{* * *} \\
(0.004)\end{array}$ \\
\hline $\begin{array}{l}\text { reviews } \\
\text { number }\end{array}$ & $\begin{array}{c}0.003^{* * *} \\
(0.000)\end{array}$ & $\begin{array}{c}0.003^{* * *} \\
(0.000)\end{array}$ & $\begin{array}{c}0.003^{* * *} \\
(0.000)\end{array}$ & $\begin{array}{c}0.000^{* * *} \\
(0.000)\end{array}$ & $\begin{array}{c}0.000^{* * *} \\
(0.000)\end{array}$ & $\begin{array}{c}0.000^{* * *} \\
(0.000)\end{array}$ \\
\hline German shop & $\begin{array}{c}0.249 * * * \\
(0.049)\end{array}$ & $\begin{array}{c}0.259^{* * *} \\
(0.049)\end{array}$ & $\begin{array}{c}0.241^{* * *} \\
(0.049)\end{array}$ & $\begin{array}{c}0.015^{* *} \\
(0.006)\end{array}$ & $\begin{array}{c}0.017^{* * *} \\
(0.006)\end{array}$ & $\begin{array}{c}0.015^{* *} \\
(0.006)\end{array}$ \\
\hline constant & $\begin{array}{c}1.696^{* * *} \\
(0.445)\end{array}$ & $\begin{array}{c}1.706^{* * *} \\
(0.444)\end{array}$ & $\begin{array}{c}1.364^{* * *} \\
(0.120)\end{array}$ & $\begin{array}{c}0.069 \\
(0.059)\end{array}$ & $\begin{array}{c}0.068 \\
(0.058)\end{array}$ & $\begin{array}{c}0.103^{* * *} \\
(0.016)\end{array}$ \\
\hline Observations & 817553 & 817553 & 817553 & 817553 & 817553 & 817553 \\
\hline No. Products & 23430 & 23430 & 23430 & 23430 & 23430 & 23430 \\
\hline $\begin{array}{l}\log \mathrm{L} \\
\chi^{2}(D F) \\
\end{array}$ & $7634(13)$ & $7542(10)$ & $\begin{array}{c}-3336965 \\
.(9) \\
\end{array}$ & $3055(13)$ & $3009(10)$ & $\begin{array}{c}-1678960 \\
.(9) \\
\end{array}$ \\
\hline
\end{tabular}

Notes: columns (1), (2), (4) and (5) show IV-Panel-regressions, columns (3) and (6) simple Panel-regressions. Dependent variable in column (1)-(3): clicks per week, dependant variable in column (4)-(6): last-click-throughs per week. Standard errors in parentheses: $* * * \mathrm{p}<0.01, * * \mathrm{p}<0.05, * \mathrm{p}<0.1$ No. Obs. $=817,553 ;$ No. firms $=628 ;$ No. products $=23,430$ 
Table 3: Focal Prices and Price Stickiness: All price offers

\begin{tabular}{|c|c|c|c|c|c|c|}
\hline & \multicolumn{3}{|c|}{ pooled } & \multicolumn{3}{|c|}{ stratified } \\
\hline & (1) & (2) & (3) & (4) & (5) & (6) \\
\hline$€ 0.99$ & $\begin{array}{c}-0.438^{* * * *} \\
(0.009)\end{array}$ & $\begin{array}{c}-0.307^{* * *} \\
(0.009)\end{array}$ & & $\begin{array}{c}-0.107^{* * *} \\
(0.010)\end{array}$ & $\begin{array}{c}-0.061^{* * * *} \\
(0.010)\end{array}$ & \\
\hline$€ 0.90$ & $\begin{array}{c}-0.408^{* * *} \\
(0.007)\end{array}$ & $\begin{array}{c}-0.371^{* * *} \\
(0.007)\end{array}$ & & $\begin{array}{c}-0.098^{* * *} \\
(0.008)\end{array}$ & $\begin{array}{c}-0.087^{* * *} \\
(0.008)\end{array}$ & \\
\hline$€ 0.50$ & $\begin{array}{c}-0.238^{* * *} \\
(0.007)\end{array}$ & $\begin{array}{c}-0.172^{* * *} \\
(0.007)\end{array}$ & & $\begin{array}{c}-0.054^{* * *} \\
(0.008)\end{array}$ & $\begin{array}{c}-0.035^{* * *} \\
(0.008)\end{array}$ & \\
\hline$€ 9.00$ & $\begin{array}{c}-0.762^{* * * *} \\
(0.009)\end{array}$ & $\begin{array}{c}-0.532^{* * *} \\
(0.010)\end{array}$ & & $\begin{array}{c}-0.194^{* * *} \\
(0.011)\end{array}$ & $\begin{array}{c}-0.131^{* * * *} \\
(0.011)\end{array}$ & \\
\hline$€ \neg 9.00$ & $\begin{array}{c}-0.443^{* * *} \\
(0.005)\end{array}$ & $\begin{array}{c}-0.374 * * * \\
(0.005)\end{array}$ & & $\begin{array}{c}-0.132^{* * *} \\
(0.007)\end{array}$ & $\begin{array}{c}-0.102^{* * *} \\
(0.007)\end{array}$ & \\
\hline 9-clustered & & & $\begin{array}{c}-0.140^{* * *} \\
(0.004)\end{array}$ & & & $\begin{array}{c}-0.013^{* * *} \\
(0.003)\end{array}$ \\
\hline even price (without 9) & & & $\begin{array}{c}-0.334^{* * *} \\
(0.005)\end{array}$ & & & $\begin{array}{c}-0.054^{* * *} \\
(0.006)\end{array}$ \\
\hline price in $100 \mathrm{~s}$ & & $\begin{array}{c}-0.003^{* * *} \\
(0.000)\end{array}$ & $\begin{array}{c}-0.003^{* * * *} \\
(0.000)\end{array}$ & & $\begin{array}{c}-0.001^{* * * *} \\
(0.000)\end{array}$ & $\begin{array}{c}-0.002 * * * \\
(0.000)\end{array}$ \\
\hline relative shipping cost & & $\begin{array}{c}-0.085^{* * *} \\
(0.004)\end{array}$ & $\begin{array}{c}-0.066^{* * *} \\
(0.004)\end{array}$ & & $\begin{array}{l}-0.006 \\
(0.005)\end{array}$ & $\begin{array}{l}-0.007 \\
(0.005)\end{array}$ \\
\hline $\begin{array}{l}\text { immediate } \\
\text { availability }\end{array}$ & & $\begin{array}{c}-0.167^{* * *} \\
(0.005)\end{array}$ & $\begin{array}{c}-0.174^{* * *} \\
(0.005)\end{array}$ & & $\begin{array}{c}0.044^{* * *} \\
(0.008)\end{array}$ & $\begin{array}{c}0.044^{* * *} \\
(0.008)\end{array}$ \\
\hline clicks & & $\begin{array}{c}-0.030^{* * *} \\
(0.002)\end{array}$ & $\begin{array}{c}-0.034^{* * *} \\
(0.002)\end{array}$ & & $\begin{array}{c}-0.021^{* * * *} \\
(0.001)\end{array}$ & $\begin{array}{c}-0.021 * * * \\
(0.001)\end{array}$ \\
\hline number of shops & & $\begin{array}{c}0.001^{* * *} \\
(0.000)\end{array}$ & $\begin{array}{c}0.001^{* * *} \\
(0.000)\end{array}$ & & $\begin{array}{c}0.001^{* * *} \\
(0.000)\end{array}$ & $\begin{array}{c}0.001^{* * *} \\
(0.000)\end{array}$ \\
\hline $\begin{array}{l}\text { price changes } \\
\text { excl. own change }\end{array}$ & & $\begin{array}{c}0.452^{* * *} \\
(0.004)\end{array}$ & $\begin{array}{c}0.458^{* * *} \\
(0.005)\end{array}$ & & $\begin{array}{c}0.425^{* * *} \\
(0.005)\end{array}$ & $\begin{array}{c}0.425^{* * *} \\
(0.005)\end{array}$ \\
\hline recommendations & & $\begin{array}{c}0.016 \\
(0.014)\end{array}$ & $\begin{array}{c}0.012 \\
(0.014)\end{array}$ & & $\begin{array}{c}0.026^{* *} \\
(0.012)\end{array}$ & $\begin{array}{c}0.026^{* *} \\
(0.012)\end{array}$ \\
\hline Observations & 803368 & 803368 & 803368 & 803368 & 803368 & 803368 \\
\hline Failures & 775735 & 775735 & 775735 & 775735 & 775735 & 775735 \\
\hline Log L & -9670155 & -9619230 & -9623473 & -5917888 & -5881645 & -5881801 \\
\hline$\chi^{2}(D F)$ & $13814(5)$ & $30824(14)$ & $22610(11)$ & $642.0(5)$ & 10291(14) & $9664(11)$ \\
\hline
\end{tabular}


Table 4: Focal Prices and Price Stickiness: Top-offers

\begin{tabular}{|c|c|c|c|c|c|c|}
\hline \multirow[t]{2}{*}{ risk: } & \multicolumn{3}{|c|}{ undercut } & \multicolumn{3}{|c|}{ own change } \\
\hline & (1) & $(2)$ & (3) & $(4)$ & $(5)$ & $(6)$ \\
\hline$€ 0.99$ & $\begin{array}{c}-0.219 * * * \\
(0.050)\end{array}$ & $\begin{array}{c}-0.235 * * * \\
(0.051)\end{array}$ & & $\begin{array}{l}0.000 \\
(0.054)\end{array}$ & $\begin{array}{l}-0.003 \\
(0.055)\end{array}$ & \\
\hline$€ 0.90$ & $\begin{array}{c}-0.114^{* *} \\
(0.049)\end{array}$ & $\begin{array}{c}-0.098^{* *} \\
(0.049)\end{array}$ & & $\begin{array}{l}-0.150^{* * *} \\
(0.040)\end{array}$ & $\begin{array}{c}-0.144^{* * *} \\
(0.041)\end{array}$ & \\
\hline$€ 0.50$ & $\begin{array}{l}-0.085 \\
(0.063)\end{array}$ & $\begin{array}{l}-0.088 \\
(0.064)\end{array}$ & & $\begin{array}{l}0.005 \\
(0.046)\end{array}$ & $\begin{array}{c}0.002 \\
(0.047)\end{array}$ & \\
\hline$€ 9.00$ & $\begin{array}{c}-0.336 * * * \\
(0.055)\end{array}$ & $\begin{array}{c}-0.311^{* * *} \\
(0.055)\end{array}$ & & $\begin{array}{l}-0.058 \\
(0.044)\end{array}$ & $\begin{array}{l}-0.061 \\
(0.044)\end{array}$ & \\
\hline$€ \neg 9.00$ & $\begin{array}{c}-0.130 * * * \\
(0.044)\end{array}$ & $\begin{array}{c}-0.134^{* * *} \\
(0.045)\end{array}$ & & $\begin{array}{l}0.014 \\
(0.035)\end{array}$ & $\begin{array}{c}0.004 \\
(0.035)\end{array}$ & \\
\hline 9-clustered & & & $\begin{array}{c}-0.089^{* * *} \\
(0.025)\end{array}$ & & & $\begin{array}{c}-0.032^{* *} \\
(0.014)\end{array}$ \\
\hline even price (without 9) & & & $\begin{array}{l}-0.070^{*} \\
(0.037)\end{array}$ & & & $\begin{array}{c}0.008 \\
(0.027)\end{array}$ \\
\hline price in $100 \mathrm{~s}$ & & $\begin{array}{l}-0.002 \\
(0.001)\end{array}$ & $\begin{array}{l}-0.002 \\
(0.001)\end{array}$ & & $\begin{array}{c}0.001^{* *} \\
(0.000)\end{array}$ & $\begin{array}{c}0.001^{* *} \\
(0.000)\end{array}$ \\
\hline relative shipping cost & & $\begin{array}{c}0.005 \\
(0.038)\end{array}$ & $\begin{array}{c}0.004 \\
(0.038)\end{array}$ & & $\begin{array}{c}-0.099 * * * \\
(0.020)\end{array}$ & $\begin{array}{c}-0.100^{* * * *} \\
(0.020)\end{array}$ \\
\hline $\begin{array}{l}\text { immediate } \\
\text { availability }\end{array}$ & & $\begin{array}{c}0.033 \\
(0.041)\end{array}$ & $\begin{array}{c}0.027 \\
(0.041)\end{array}$ & & $\begin{array}{c}0.008 \\
(0.023)\end{array}$ & $\begin{array}{c}0.006 \\
(0.023)\end{array}$ \\
\hline $\begin{array}{c}\text { clicks while } \\
\text { in lead }\end{array}$ & & $\begin{array}{c}0.020^{* * *} \\
(0.002)\end{array}$ & $\begin{array}{c}0.020^{* * *} \\
(0.002)\end{array}$ & & $\begin{array}{c}0.015^{* * *} \\
(0.002)\end{array}$ & $\begin{array}{c}0.015^{* * *} \\
(0.002)\end{array}$ \\
\hline number of shops & & $\begin{array}{c}0.006^{* * *} \\
(0.000)\end{array}$ & $\begin{array}{c}0.006^{* * *} \\
(0.000)\end{array}$ & & $\begin{array}{c}0.001^{* * *} \\
(0.000)\end{array}$ & $\begin{array}{c}0.001^{* * *} \\
(0.000)\end{array}$ \\
\hline $\begin{array}{l}\text { price changes } \\
\qquad(\text { excl. own changes })\end{array}$ & & $\begin{array}{c}2.475^{* * *} \\
(0.375)\end{array}$ & $\begin{array}{c}2.485^{* * *} \\
(0.376)\end{array}$ & & $\begin{array}{c}3.376^{* * *} \\
(0.449)\end{array}$ & $\begin{array}{c}3.376^{* * *} \\
(0.449)\end{array}$ \\
\hline recommendations & & $\begin{array}{c}0.141^{* *} \\
(0.058)\end{array}$ & $\begin{array}{c}0.136^{* *} \\
(0.058)\end{array}$ & & $\begin{array}{l}-0.013 \\
(0.030)\end{array}$ & $\begin{array}{l}-0.013 \\
(0.030)\end{array}$ \\
\hline Observations & 41574 & 41574 & 41574 & 41574 & 41574 & 41574 \\
\hline Failures & 14928 & 14928 & 14928 & 26632 & 26632 & 26632 \\
\hline $\log \mathrm{L}$ & -79812 & -79206 & -79223 & -150883 & -150690 & -150694 \\
\hline$\chi^{2}(D F)$ & $50.64(5)$ & $618.7(13)$ & $574.1(10)$ & $17.37(5)$ & $254.9(13)$ & $236.3(10)$ \\
\hline
\end{tabular}

Notes: Competing risk Cox hazard model with cluster-robust standard errors, stratified at the firm level. Dependent variable: duration top. Observations: 41,574; failures in the group of undercut (actively changed) offers: 14,928 (26,632; and 14 offers which were valid more than 43 days)); Number of firms $\mathrm{j}$ in estimation $=522$; Number of products $\mathrm{i}=13,471$; Number of different offers $\mathrm{ij}=21,759$. Standard errors in parentheses: ${ }^{* * *} \mathrm{p}<0.01,{ }^{* *} \mathrm{p}<0.05,{ }^{*} \mathrm{p}<0.1$. 